Article

\title{
Copolymerization of Norbornene and Styrene with Anilinonaphthoquinone-Ligated Nickel Complexes
}

\author{
Samiul Islam Chowdhury $(\mathbb{D}$, Ryo Tanaka $₫$, Yuushou Nakayama $₫$ and Takeshi Shiono *(1) \\ Graduate School of Engineering, Hiroshima University, Hiroshima 739-8527, Japan \\ * Correspondence: tshiono@hiroshima-u.ac.jp; Tel.: +81-824-24-773
}

Received: 4 June 2019; Accepted: 26 June 2019; Published: 28 June 2019

\begin{abstract}
Poly(norbornene-co-styrene)s were synthesized by the use of anilinonaphthoquinone-ligated nickel complexes [ $\mathrm{Ni}\left(\mathrm{C}_{10} \mathrm{H}_{5} \mathrm{O}_{2} \mathrm{NAr}\right)(\mathrm{Ph})\left(\mathrm{PPh}_{3}\right): \mathbf{1 a}, \mathrm{Ar}=\mathrm{C}_{6} \mathrm{H}_{3}-2,6-{ }^{i} \mathrm{Pr} ; \mathbf{1 b}, \mathrm{Ar}=\mathrm{C}_{6} \mathrm{H}_{2}-2,4,6-\mathrm{Me} ; \mathbf{1 c}$,

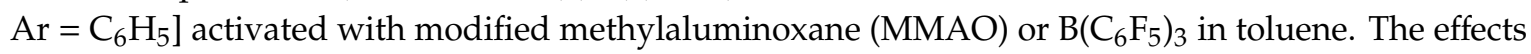
of the cocatalysts were more significant than those of the nickel complexes, and MMAO gave higher activity than $\mathrm{B}\left(\mathrm{C}_{6} \mathrm{~F}_{5}\right)_{3}$. The structural characterizations of the products indicated the formation of statistical norbornene copolymers. An increase of the styrene ratio in feed led to an increase in the incorporated styrene (S) content of the resulting copolymer. The molecular weight of the copolymer decreased with increasing the $S$ ratio in feed at $70{ }^{\circ} \mathrm{C}$. The copolymerization activity, using MMAO as a cocatalyst, decreased with lowering of the temperature from 70 to $0{ }^{\circ} \mathrm{C}$, accompanied by an increase in the molecular weight of the copolymer. The $S$ incorporation up to $59 \%$ with $M_{n}$ of 78,000 was achieved by the $1 \mathrm{~b}-\mathrm{B}\left(\mathrm{C}_{6} \mathrm{~F}_{5}\right)_{3}$ catalytic system. The glass transition temperatures of the norbornene $(\mathrm{N}) / \mathrm{S}$ copolymers determined by differential scanning calorimetry, decreased from 329 to $128{ }^{\circ} \mathrm{C}$ according to the $\mathrm{S}$ content.
\end{abstract}

Keywords: nickel catalyst; copolymerization; norbornene; styrene

\section{Introduction}

The polymerization of cycloolefins such as norbornene $(\mathrm{N})$ has been one of the key developments in the area of polymer chemistry because of its vast range of applications [1-3]. There are three types of mechanism for polymerization of $\mathrm{N}$, which are ring-opening metathesis polymerization (ROMP) $[4,5]$, cationic or radical polymerization [6-9], and coordination-insertion polymerization [10-12]. Each route of the polymerization leads to the polymers with different structures and properties. Polynorbornenes (PNBs) produced by coordination-insertion polymerization show excellent physical properties, such as good heat and chemical resistance, high decomposition temperature, high optical transparency, and low dielectric constant $[13,14]$, but exhibit some negative properties such as brittleness and glass transition temperature $\left(T_{g}\right)$ close to the decomposition temperature due to the presence of a rigid ring in the polymer chain.

The inferior properties of PNBs can be improved in cyclic olefin copolymers (COCs). The most representative COC is a copolymer of $\mathrm{N}$ and ethylene (E) [15]. The properties of COCs can be easily controlled by a kind of comonomer, comonomer content, and sequence distribution. Copolymerization of $\mathrm{N}$ with 1-alkene was also reported to modify the physical properties [16-24]. The introduction of styrene (S) should decrease the birefringence of COCs [25] because PNB and polystyrene possess positive and negative birefringence, respectively. Several examples of the copolymerization of $\mathrm{N}$ with $\mathrm{S}$ have been reported. The first N/S copolymerization was achieved by Ni-based catalysts using methylaluminoxane (MAO) as a cocatalyst [26]. Afterwards, some nickel and copper catalysts were used to synthesize N/S copolymers [27-33]. The S incorporation was improved by $\beta$-diketiminato nickel complexes [34]. The highest $\mathrm{S}$ incorporation was $52.4 \%$, with the highest $\mathrm{S}$ feed ratio of $83 \%$, but the $M_{w}$ value was 
around $10^{3}$. Recently, bis( $\beta$-ketoamino) copper complexes were used for copolymerization of $\mathrm{N}$ and $\mathrm{S}$, whereas the results were almost the same as those of $\beta$-diketiminato nickel complexes [35].

We have also reported N/S copolymerization by an ansa-fluorenylamidodimethyltitanium-based catalyst and shown the potentiality of the copolymer as a plastic substrate for flexible display materials [25]. However, the maximum $\mathrm{S}$ incorporation in the N/S copolymer with sufficient molecular weight was approximately $5 \mathrm{~mol} \%$. We have synthesized N/E/S terpolymer by using the same catalyst and obtained a zero-birefringence terpolymer with the $S$ content of $12 \%$, but the introduction of $E$ unit (58 $\mathrm{mol} \%$ ) caused a significant drop of the $T_{g}$ to $86^{\circ} \mathrm{C}$ [36].

Therefore, we are interested in the copolymerization of $\mathrm{N}$ with $\mathrm{S}$ to obtain high molecular weight copolymers with controlled $S$ content. We have previously reported that anilinonaphthoquinone-ligated nickel complexes activated with $\mathrm{B}\left(\mathrm{C}_{6} \mathrm{~F}_{5}\right)_{3}$ as a cocatalyst exhibit high activity for $\mathrm{N}$ polymerization to give high molecular weight polymer soluble in cyclohexane [37]. In the present paper, we report the $\mathrm{N} / \mathrm{S}$ copolymerization using nickel complexes $\left[\mathrm{Ni}\left(\mathrm{C}_{10} \mathrm{H}_{5} \mathrm{O}_{2} \mathrm{NAr}\right)(\mathrm{Ph})\left(\mathrm{PPh}_{3}\right): \mathbf{1 a}, \mathrm{Ar}=\mathrm{C}_{6} \mathrm{H}_{3}-2,6-{ }^{i} \mathrm{Pr} ; \mathbf{1} \mathbf{b}\right.$, $\mathrm{Ar}=\mathrm{C}_{6} \mathrm{H}_{2}-2,4,6-\mathrm{Me} ; \mathbf{1} \mathbf{c}, \mathrm{Ar}=\mathrm{C}_{6} \mathrm{H}_{5}$ ], where $\mathbf{1} \mathbf{c}$ was newly synthesized in this work, in the presence of modified MAO (MMAO) or $\mathrm{B}\left(\mathrm{C}_{6} \mathrm{~F}_{5}\right)_{3}$ (Figure 1).<smiles>[R]C1=CC([R])=C2C([R])=C(N(P)Pc3ccccc31)N2C1=CC(=O)c2ccccc2C1=O</smiles>

1a. $\mathrm{R}=\mathrm{CH}\left(\mathrm{CH}_{3}\right)_{2}, \mathrm{R}^{1}=\mathrm{H}$.

1b. $\mathrm{R}=\mathrm{R}^{1}=\mathrm{CH}_{3}$.

1c. $R=R^{1}=H$.

Figure 1. Anilinonaphthoquinone-ligated nickel complexes used in this study.

\section{Materials and Methods}

\subsection{Materials}

All manipulations were carried out under a nitrogen atmosphere using standard Schlenk techniques. All solvents were refluxed and distilled over sodium/benzophenone or calcium hydride. Norbornene was purified by stirring it over calcium hydride at $60^{\circ} \mathrm{C}$ for one day, and then distilled. The stock solution of N (5.5 M) was prepared in toluene. Styrene (Wako Chemical Co. Ltd., Odawara, Japan) was dried over $\mathrm{CaH}_{2}$, and then freshly distilled under vacuum prior to use. Modified methylaluminoxane (MMAO) solution $\left(6.6 \mathrm{wt} \% \text { in toluene) and toluene solution of } \mathrm{B}_{(} \mathrm{C}_{6} \mathrm{~F}_{5}\right)_{3}$ were donated from Tosoh Finechem. Co. (Tokyo, Japan) and used as received. The nickel complexes 1a,1 $\mathbf{1 b}$ were synthesized according to the literature and the references therein $[38,39]$. The complex $\mathbf{1 c}$ was synthesized using a similar procedure to that for $\mathbf{1 a}$ and $\mathbf{1 b}$ (Supporting Information).

\subsection{Analytical Procedure}

Molecular weights and molecular weight distributions of polymers were determined by gel permeation chromatography (GPC) with a Viscotec HT-350 GPC (Malvern, Great Malvern, UK) with one guard column and two $30 \mathrm{~cm}$ columns. This system was equipped with a triple-detection array consisting of a differential refractive index (DRI) detector, a two-angle $(7,90)$ light scattering (LS) detector, and a four-bridge capillary viscosity detector. Polymer characterization was carried out at $150{ }^{\circ} \mathrm{C}$ using $o$-dichlorobenzene as an eluent, and calibrated with polystyrene standards. The ${ }^{1} \mathrm{H}$ and ${ }^{13} \mathrm{C}$ NMR spectra of polymers were measured at room temperature on a Bruker $500 \mathrm{M} \mathrm{Hz}$ instrument (Bruker, Rheinstetten, Germany) operated by the pulse Fourier-transform mode. Sample solution of ${ }^{13} \mathrm{C} \mathrm{NMR}$ was prepared in $\mathrm{CDCl}_{3}$ up to $10 \mathrm{wt} \%$, and the pulse angle was $45^{\circ}$, and about $8000-10,000$ scans were accumulated in pulse repetition of $5.0 \mathrm{~s}$. The central peak of $\mathrm{CDCl}_{3}\left(7.13 \mathrm{ppm}\right.$ for ${ }^{1} \mathrm{H}$ and $77.13 \mathrm{ppm}$ for ${ }^{13} \mathrm{C}$ NMR) was used as an internal reference. Differential scanning calorimetry (DSC) was performed on a SII EXSTER 600 system (Seiko Instruments Inc., Chiba, Japan) under nitrogen 
atmosphere. Thermal history difference in the polymers was eliminated by first heating the specimen to $380^{\circ} \mathrm{C}$, cooling from 10 to $20^{\circ} \mathrm{C} / \mathrm{min}$, and then recording the second DSC scan at a heating rate of $10^{\circ} \mathrm{C} / \mathrm{min}$.

\subsection{Copolymerization of $N$ and $S$}

In a typical procedure, prescribed amounts of $\mathrm{N}$ and $\mathrm{S}$ in toluene solution were introduced into a $100 \mathrm{~mL}$ round-bottomed glass flask. Then, the cocatalyst $(0.24 \mathrm{~mL} 500 \mu \mathrm{mol}$ of MMAO toluene solution or $1 \mathrm{~mL} 20 \mu \mathrm{mol}$ of $\mathrm{B}\left(\mathrm{C}_{6} \mathrm{~F}_{5}\right)_{3}$ toluene solution) and $1 \mathrm{~mL}$ of the nickel complex $(5 \mu \mathrm{mol})$ solution in toluene were syringed into the well-stirred monomer solution in this order, and the total solution volume was made up to $25 \mathrm{~mL}$ by adding toluene. The copolymerization was conducted under continuous stirring for a required time under a certain temperature as controlled using an external oil or ice bath. The copolymerization was terminated by adding $300 \mathrm{~mL}$ of acidic methanol (methanol/concentrated hydrochloric acid, 95: 5 in volume). The resulting precipitated polymer was collected by filtration, adequately washed with methanol, and dried in vacuum at $60^{\circ} \mathrm{C}$ for $6 \mathrm{~h}$.

\section{Results and Discussion}

\subsection{Homopolymerization of $N$ and $S$}

Homopolymerizations of $\mathrm{N}$ and $\mathrm{S}$ were performed using 1-MMAO at $70{ }^{\circ} \mathrm{C}$ in toluene. The results are shown in Table 1. In the $\mathrm{N}$ polymerization, complex 1a displayed the highest activity, and gave the polymer with the highest molecular weight among the complexes used. The opposite trends were observed in $\mathrm{S}$ polymerization, but the differences were not significant.

Table 1. Effects of monomer ratio of norbornene (N)/styrene (S) copolymerization by 1-MMAO.

\begin{tabular}{|c|c|c|c|c|c|c|c|c|}
\hline Run & $\begin{array}{c}\mathrm{N} / \mathrm{S}^{\mathrm{a}} \\
(\mathrm{mmol} / \mathrm{mmol})\end{array}$ & Complex & $\begin{array}{l}\text { Yield } \\
\text { (g) }\end{array}$ & Act. ${ }^{b}$ & $\begin{array}{c}f_{S}{ }^{\mathrm{c}} \\
(\mathrm{mol} \%)\end{array}$ & $\begin{array}{c}M_{n} \\
\left(10^{3}\right)\end{array}$ & $M_{w} / M_{n}^{\mathrm{d}}$ & $\begin{array}{c}N^{\mathrm{e}} \\
(\mu \mathrm{mol})\end{array}$ \\
\hline 1 & $40 / 00$ & 1a & 1.10 & 220 & 0 & 470 & 1.9 & 2.3 \\
\hline 2 & $40 / 10$ & 1a & 0.36 & 72 & 4 & 19 & 2.4 & 18.9 \\
\hline 3 & $40 / 40$ & $1 \mathrm{a}$ & 0.65 & 130 & 16 & 6 & 2.5 & 108.3 \\
\hline 4 & $00 / 40$ & $1 \mathrm{a}$ & 0.52 & 104 & 100 & 11 & 1.5 & 47.2 \\
\hline 5 & $40 / 00$ & $1 b$ & 0.54 & 107 & 0 & 266 & 2.2 & 2.0 \\
\hline 6 & $40 / 10$ & $1 b$ & 0.37 & 74 & 4 & 19 & 2.7 & 19.5 \\
\hline 7 & $40 / 20$ & $1 b$ & 0.31 & 62 & 8 & 12 & 1.7 & 25.8 \\
\hline 8 & $40 / 30$ & $1 b$ & 0.30 & 60 & 12 & 9 & 3.0 & 33.3 \\
\hline 9 & $40 / 40$ & $1 b$ & 0.44 & 88 & 19 & 8 & 2.9 & 55.0 \\
\hline 10 & $00 / 40$ & $1 b$ & 0.65 & 130 & 100 & 12 & 1.6 & 54.2 \\
\hline 11 & $40 / 00$ & 1c & 0.58 & 115 & 0 & 309 & 1.6 & 1.9 \\
\hline 12 & $40 / 10$ & $1 c$ & 0.36 & 72 & 10 & 13 & 2.0 & 27.7 \\
\hline 13 & $40 / 20$ & 1c & 0.32 & 64 & 16 & 10 & 1.5 & 32.0 \\
\hline 14 & $40 / 30$ & 1c & 0.31 & 62 & 19 & 8 & 1.9 & 38.6 \\
\hline 15 & $40 / 40$ & $1 c$ & 0.40 & 80 & 36 & 7 & 3.0 & 57.1 \\
\hline 16 & $00 / 40$ & $1 c$ & 0.65 & 130 & 100 & 14 & 1.7 & 46.4 \\
\hline
\end{tabular}

Copolymerization conditions: $\mathrm{Ni}=5 \mu \mathrm{mol}$, temperature $=70^{\circ} \mathrm{C}$, time $=1 \mathrm{~h}, \mathrm{Al} / \mathrm{Ni}=100$ (molar ratio), toluene (total volume $25 \mathrm{~mL}$ ). ${ }^{\mathrm{a}}$ Norbornene and styrene in feed. ${ }^{\mathrm{b}}$ Activity $=\mathrm{kg}_{(\text {polymer })} \mathrm{mol}_{(\mathrm{Ni})}{ }^{-1} \mathrm{~h}^{-1}$. ${ }^{\mathrm{c}} f_{S}$ is the content of $\mathrm{S}$ in the N/S copolymer determining by ${ }^{1} \mathrm{H}$ NMR spectrum. ${ }^{\mathrm{d}}$ Determined by GPC. ${ }^{\mathrm{e}}$ Number of polymer chains determined from yield and $M_{n}$.

\subsection{Copolymerization of $N$ and $S$}

Copolymerizations of $\mathrm{N}$ with $\mathrm{S}$ were then conducted under the same conditions by changing $\mathrm{S}$ in feed from 10 to $40 \mathrm{mmol}$, with $40 \mathrm{mmol}$ of $\mathrm{N}$ (Scheme 1). 


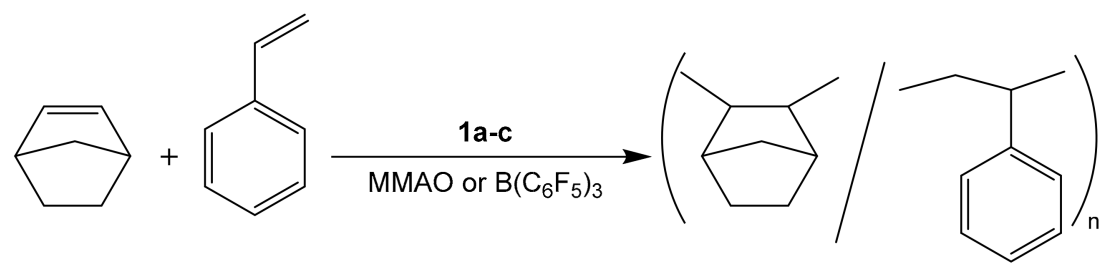

Scheme 1. N/S copolymerization with Ni catalyst.

The results are summarized in Table 1 . The nickel complexes showed moderate activity for N/S copolymerization. The N/S feed ratio did not significantly affect the catalytic activity, and all the complexes showed lower activity in the copolymerizations than in homopolymerizations. The low activity in the copolymerization could be ascribed to slow cross-propagation because of the steric hindrance between these comonomers. Complex 1a, which showed the highest activity in $\mathrm{N}$ polymerization, also showed the highest activity in N/S copolymerization among the complexes used (Table 1, Run 3).

The N/S copolymers were not only soluble in chloroform, but also in cyclohexane, similar to the PNB obtained by the same catalytic system. The incorporation of $S$ in the produced copolymers was investigated by ${ }^{1} \mathrm{H} \mathrm{NMR}$ in $\mathrm{CDCl}_{3}$. A typical ${ }^{1} \mathrm{H}$ NMR spectrum of the copolymer (Run 15) is illustrated in Figure 2i. No resonances are observed from 5.0 to $6.0 \mathrm{ppm}$, which is assigned to the vinylene protons of the polymer obtained via ring-opening metathesis polymerization (ROMP) [40].

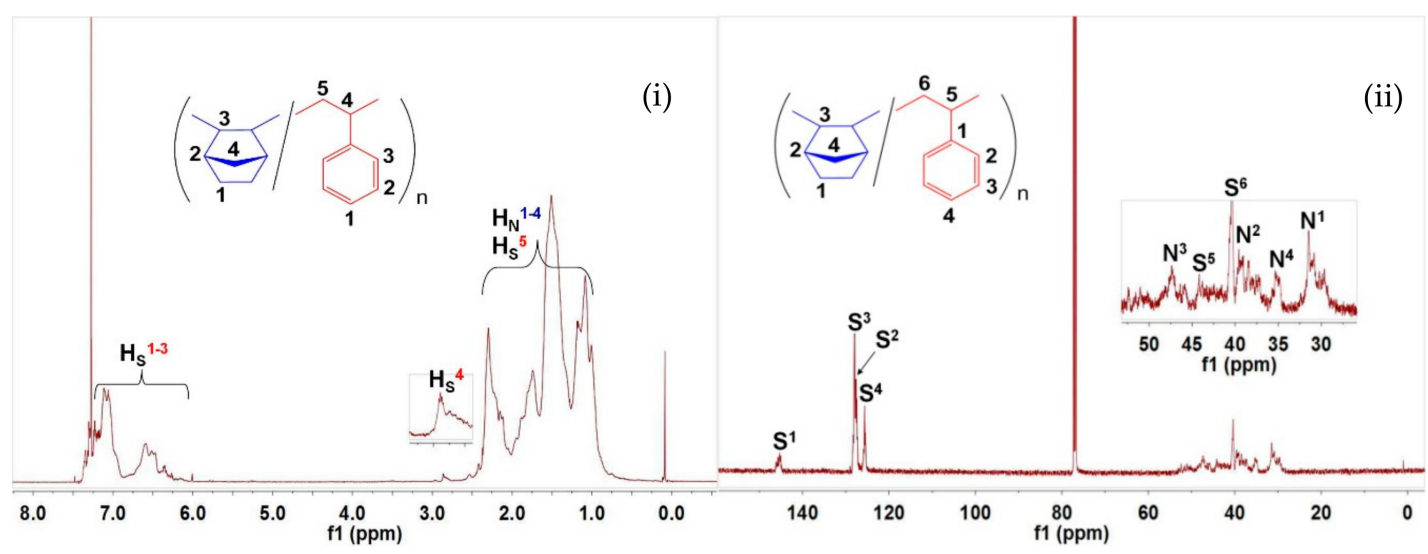

Figure 2. ${ }^{1} \mathrm{H}$ NMR (i) and ${ }^{13} \mathrm{C}$ NMR (ii) spectra of N/S copolymer obtained by Run $15\left(\mathrm{CDCl}_{3}, \mathrm{rt}\right.$, $500 \mathrm{MHz}$ ).

The signals assignable to the aliphatic protons of the $\mathrm{N}$ and $\mathrm{S}$ units $\left(\mathrm{H}_{\mathrm{N}}{ }^{1-4}\right.$ and $\left.\mathrm{H}_{\mathrm{S}}{ }^{5}\right)$ are observed in the range of $0.8-2.4 \mathrm{ppm}$. The signals attributed to the aromatic protons of the $\mathrm{S}$ units $\left(\mathrm{H}_{\mathrm{S}}{ }^{1-3}\right)$ are observed in the range of 6.5-7.1 ppm. Particularly, the signal of the methine proton of the $S$ unit $\left(\mathrm{H}_{\mathrm{S}}{ }^{4}\right)$ adjacent to the $\mathrm{N}$ unit can be observed at $2.85 \mathrm{ppm}$. The ${ }^{1} \mathrm{H}$ NMR spectra of the polymers obtained under the highest styrene concentration (Table 1, Run 3, 9 and 15) are shown in Supplementary Figure S5.

A typical ${ }^{13} \mathrm{C}$ NMR spectrum of the copolymer (Run 15) is shown in Figure 2ii. According to the reported assignment of the N/S copolymer, [34] the signals of each chemical shift region were assigned as follows: $145.7 \mathrm{ppm}$ for $C^{1}, 127.3 \mathrm{ppm}$ for $C^{2}, 127.9 \mathrm{ppm}$ for $C^{3}, 125.6$ for $C^{4}, 41.5-44.2$, and $40.5 \mathrm{ppm}$ for $\mathrm{C}^{5}$ and $\mathrm{C}^{6}$ of the $S$ segment, $47.1-52.5 \mathrm{ppm}$ for $\mathrm{C}^{3}, 38-39.7 \mathrm{ppm}$ for $\mathrm{C}^{2}, 34.5-37 \mathrm{ppm}$ for $\mathrm{C}^{4}$, and 29.4-31.9 ppm for $\mathrm{C}^{1}$ of the $\mathrm{N}$ unit. A clear observation of the phenyl-carbons of the $\mathrm{S}$ units in the regions of 125-145 ppm also indicates the presence of the $S$ units in the N/S copolymer. These results are similar to those obtained in the previously reported nickel-MAO catalytic system and confirm the random distribution of $S$ unit in the obtained N/S copolymer [34]. 
The incorporation of $S$ increased with increasing $S$ concentration in the monomer feed ratio. The highest $S$ content in the N/S copolymer was achieved to be $36 \%$ at $1: 1$ feed ratio by complex $1 \mathrm{c}$ probably because of less interaction between the ligand substituent and the aromatic ring of $S$.

The molecular weight of N/S copolymer was measured by GPC. The increase of $S$ concentration in feed caused the decrease in the molecular weights of the produced polymers accompanied by the increase in the number of polymer chains, which is ascribed to $\beta$-hydrogen elimination of the increased styryl propagation end [41]. Unimodal distribution $\left(M_{w} / M_{n} \approx 2\right)$ indicates that the copolymerization should take place at a single active site (Supplementary Figure S6).

\subsection{Effect of Polymerization Temperature on N/S Copolymerization:}

The influence of reaction temperature on N/S copolymerization was studied using 1-MMAO at the fixed feeding ratio (N/S = 4:1 in molar ratio), because the low $\mathrm{S}$ feed ratio gave high molecular weight N/S copolymer. The results are summarized in Table 2.

Table 2. Effects of temperature of N/S copolymerization by 1-MMAO.

\begin{tabular}{|c|c|c|c|c|c|c|c|c|}
\hline Run & Complex & $\begin{array}{c}\text { Temperature } \\
\left({ }^{\circ} \mathrm{C}\right)\end{array}$ & Yield (g) & Activity ${ }^{a}$ & $\underset{(\mathrm{mol} \%)}{f_{S}{ }^{b}}$ & $\begin{array}{l}M_{n}^{\mathrm{c}} \\
\left(10^{3}\right)\end{array}$ & $M_{w} / M_{n}^{c}$ & $T_{g}{ }^{\mathrm{d}}$ \\
\hline 2 & 1a & 70 & 0.36 & 72 & 4 & 19 & 2.4 & 321 \\
\hline 17 & 1a & 50 & 0.27 & 54 & 7 & 26 & 2.2 & 289 \\
\hline 18 & $1 \mathrm{a}$ & 30 & 0.14 & 28 & 9 & 27 & 2.0 & 267 \\
\hline 19 & $1 \mathrm{a}$ & 0 & 0.13 & 26 & 20 & 55 & 2.1 & 219 \\
\hline 6 & $1 b$ & 70 & 0.37 & 74 & 4 & 19 & 2.7 & 329 \\
\hline 20 & $1 b$ & 50 & 0.27 & 54 & 9 & 24 & 2.2 & 263 \\
\hline 21 & $1 b$ & 30 & 0.20 & 40 & 12 & 27 & 2.3 & 252 \\
\hline 22 & $1 b$ & 0 & 0.11 & 22 & 30 & 57 & 1.5 & 175 \\
\hline 12 & $1 c$ & 70 & 0.36 & 72 & 10 & 13 & 2.0 & 251 \\
\hline 23 & $1 c$ & 50 & 0.29 & 58 & 16 & 18 & 2.2 & 227 \\
\hline 24 & $1 c$ & 30 & 0.24 & 48 & 21 & 54 & 1.5 & 212 \\
\hline 25 & $1 \mathrm{c}$ & 0 & 0.14 & 27 & 32 & 61 & 1.5 & 172 \\
\hline
\end{tabular}

Copolymerization conditions: $\mathrm{Ni}=5 \mu \mathrm{mol}, \mathrm{Al} / \mathrm{Ni}=100$ (molar ratio), $\mathrm{N} / \mathrm{S}=4: 1$ (molar ratio), toluene (total volume $25 \mathrm{~mL}$ ) time $1 \mathrm{~h}$. ${ }^{\mathrm{a}}$ Activity $=\mathrm{kg}_{\text {(polymer) }} \mathrm{mol}_{(\mathrm{Ni})}{ }^{-1} \mathrm{~h}^{-1}$. ${ }^{\mathrm{b}} f_{\mathrm{S}}$ is the content of $\mathrm{S}$ in the N/S copolymer determining by

${ }^{1} \mathrm{H}$ NMR spectrum. ${ }^{\mathrm{c}}$ Determined by GPC. ${ }^{\mathrm{d}}$ Determined by DSC.

The copolymerization activity decreased with lowering the temperature from 70 to $0{ }^{\circ} \mathrm{C}$. The highest activity around $70 \mathrm{~kg}$ polymer/(mol $\mathrm{Ni} \mathrm{h})$ for the copolymerization was achieved at $70{ }^{\circ} \mathrm{C}$ in each system. On the other hand, the S content and the $M_{n}$ value monotonously increased with lowering of the polymerization temperature (Supplementary Figure S7), and the N/S copolymer with $32 \mathrm{~mol} \%$ of $\mathrm{S}$ and 61,000 of $M_{n}$ was obtained at $0{ }^{\circ} \mathrm{C}$ by $1 \mathrm{c}-\mathrm{MMAO}$ (Table 2, Run 25, Figure 3i). This $M_{n}$ value would be the highest among the N/S copolymers reported so far [25,34,35]. The molecular weight distribution became narrow with decreasing the polymerization temperature. A decreased $M_{n}$ value of the copolymers obtained with an increase in the reaction temperature is ascribed to the chain transfer at high temperature [32].

The $T_{g}$ values of N/S copolymers were analyzed by DSC. The $T_{g}$ value declined with an increase of $\mathrm{S}$ content as shown in Figure 3ii. The highest value of $329^{\circ} \mathrm{C}$ (Supplementary Figure S8), and the lowest value of $172{ }^{\circ} \mathrm{C}$, were detected for the copolymers with 4 and $32 \mathrm{~mol} \%$ of S, respectively (Table 2, Run 6 and 25). A previous study has shown that the $T_{g}$ value of the PNBs obtained with this catalyst was over $400{ }^{\circ} \mathrm{C}$ [37]. The $T_{g}$ value of polystyrene is $100^{\circ} \mathrm{C}$. The single $T_{g}$ value in the DSC curves reveal that $\mathrm{N}$ and $\mathrm{S}$ were uniformly distributed in the N/S copolymers obtained by the present catalysts. 

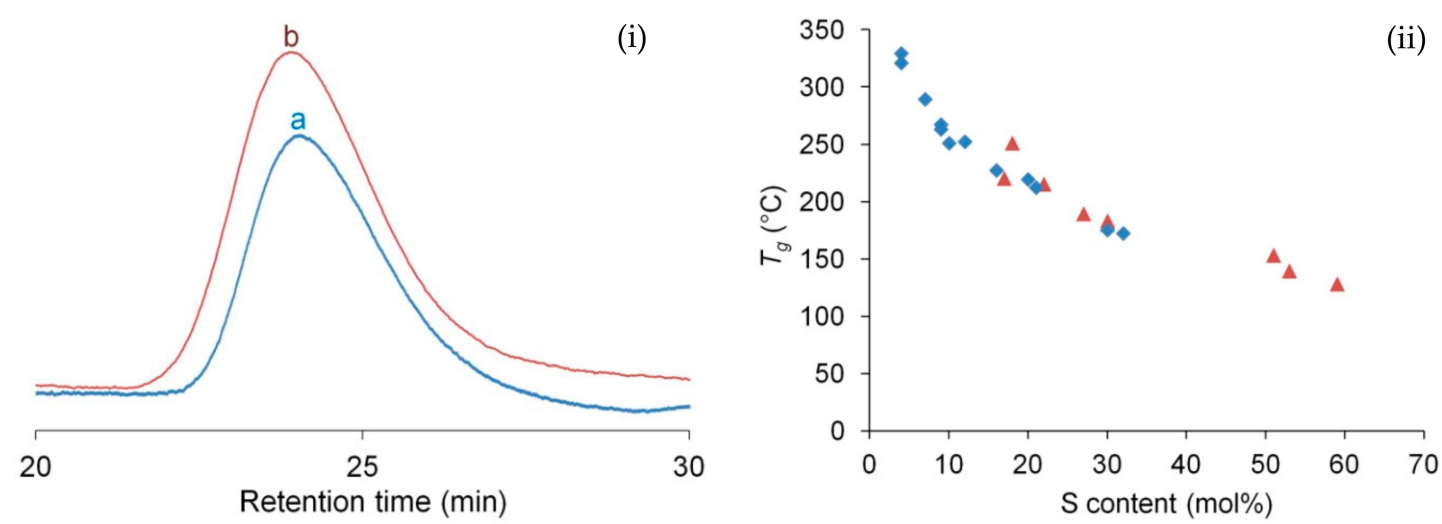

Figure 3. (i) GPC traces of N/S copolymers: a, Run $24 ; \mathbf{b}$, Run 25 (ii) $\mathrm{S}$ content versus $T_{g}$ plot obtained by Ni complexes: $\bullet, \mathrm{MMAO} ; \mathbf{\Delta}, \mathrm{B}\left(\mathrm{C}_{6} \mathrm{~F}_{5}\right)_{3}$.

\subsection{N/S Copolymerization by $1-B\left(C_{6} F_{5}\right)_{3}$ :}

We found the considerable effects of temperature on N/S copolymerization using the 1-MMAO system. We observed significant effects of $\mathrm{B}\left(\mathrm{C}_{6} \mathrm{~F}_{5}\right)_{3}$ in E polymerization [38] and N polymerization [37] with 1a, which were ascribed to the formation of zwitterionic nickel species [39].

Thus, the N/S copolymerization (N/S $=4: 1$ in molar ratio) by the $1-B\left(C_{6} F_{5}\right)_{3}$ system, was conducted at different temperatures $\left(30,50\right.$, and $\left.70{ }^{\circ} \mathrm{C}\right)$ to investigate the cocatalyst effect.

The activity of the $\mathrm{B}\left(\mathrm{C}_{6} \mathrm{~F}_{5}\right)_{3}$ system was lower than that of the MMAO system. The incorporation of $\mathrm{S}$ increased with lowering the temperature, as was observed in the 1-MMAO system. The $\mathrm{S}$ incorporation was almost four times higher than those of the copolymers produced by the 1-MMAO system. The highest $\mathrm{S}$ incorporation was observed at $30^{\circ} \mathrm{C}$ (Supplementary Figure S9), 51 59\% with the $M_{n}$ values (Supplementary Figure S10) of 43,000 78,000 (Table 3, Run 28, 31, and 34).

Table 3. Effects of temperature of N/S copolymers by $1-B\left(C_{6} F_{5}\right)_{3}$.

\begin{tabular}{|c|c|c|c|c|c|c|c|c|}
\hline Run & Complex & $\begin{array}{l}\text { Temperature } \\
\left({ }^{\circ} \mathrm{C}\right)\end{array}$ & $\begin{array}{l}\text { Yield } \\
\text { (g) }\end{array}$ & Activity $^{a}$ & $\underset{(\mathrm{mol} \%)}{f_{S}{ }^{\mathrm{b}}}$ & $\begin{array}{l}M_{n}{ }^{c} \\
\left(10^{3}\right)\end{array}$ & $M_{w} / M_{n}^{c}$ & $T_{g}{ }^{\mathrm{d}}$ \\
\hline 26 & 1a & 70 & 0.126 & 26 & 17 & 36 & 1.9 & 220 \\
\hline 27 & 1a & 50 & 0.072 & 15 & 22 & 40 & 1.7 & 215 \\
\hline 28 & 1a & 30 & 0.053 & 11 & 51 & 43 & 1.9 & 153 \\
\hline 29 & $1 b$ & 70 & 0.088 & 18 & 18 & 38 & 2.0 & 251 \\
\hline 30 & $1 b$ & 50 & 0.067 & 14 & 30 & 55 & 1.6 & 183 \\
\hline 31 & $1 b$ & 30 & 0.033 & 7 & 59 & 78 & 1.9 & 128 \\
\hline 32 & 1c & 70 & 0.082 & 17 & 27 & 38 & 2.5 & 189 \\
\hline 33 & 1c & 50 & 0.034 & 7 & 30 & 39 & 2.1 & 180 \\
\hline 34 & $1 c$ & 30 & 0.030 & 6 & 53 & 46 & 2.0 & 139 \\
\hline $35^{[\mathrm{e}]}$ & $1 \mathrm{a}$ & 70 & 0.330 & 66 & 17 & 103 & 1.4 & 232 \\
\hline
\end{tabular}

Copolymerization conditions: $\mathrm{Ni}=5 \mu \mathrm{mol}, \mathrm{B} / \mathrm{Ni}=4$ (molar ratio), $\mathrm{N} / \mathrm{S}=4: 1$ (molar ratio), toluene (total volume $25 \mathrm{~mL}$ ) time $=1 \mathrm{~h} .{ }^{\mathrm{a}}$ Activity $=\mathrm{kg}_{\text {(polymer) }} \mathrm{mol}_{(\mathrm{Ni})}{ }^{-1} \mathrm{~h}^{-1} .{ }^{\mathrm{b}} f_{S}$ is the content of $\mathrm{S}$ in the N/S copolymer determining by ${ }^{1} \mathrm{H}$ NMR spectrum. ${ }^{\mathrm{c}}$ Determined by GPC. ${ }^{\mathrm{d}}$ Determined by DSC. ${ }^{\mathrm{e}} \mathrm{B}\left(\mathrm{C}_{6} \mathrm{~F}_{5}\right)_{3} /{ }^{t} \mathrm{BuAl} / \mathrm{BHT}=1: 10: 20$.

In order to evaluate the effects of the cocatalysts on N/S copolymerization, the monomer reactivity ratios of $\mathbf{1 b}$ were determined at $70^{\circ} \mathrm{C}$ (Supplementary Table S1). The Fineman-Ross plots of $\mathbf{1 b}$-MMAO and $\mathbf{1 b}-\mathrm{B}\left(\mathrm{C}_{6} \mathrm{~F}_{5}\right)_{3}$ for $\mathrm{N} / \mathrm{S}$ copolymerization are shown in Figure $4 \mathrm{i}$ and $4 \mathrm{ii}$, respectively. The monomer reactivity ratios were determined to be $r_{\mathrm{N}}=6.34$ and $r_{\mathrm{S}}=0.39$ for $1 \mathrm{~b}-\mathrm{MMAO}$, and $r_{\mathrm{N}}=0.93$ and $r_{\mathrm{S}}=0.13$ for $1 \mathbf{b}-\mathrm{B}\left(\mathrm{C}_{6} \mathrm{~F}_{5}\right)_{3}$, indicating the better copolymerization ability of the $\mathrm{B}\left(\mathrm{C}_{6} \mathrm{~F}_{5}\right)_{3}$ cocatalyst. The reactivity ratios of $1 \mathrm{c}-\mathrm{MMAO}$ were also determined to evaluate the effects of the complexes (Supplementary Figure S11). The values $r_{\mathrm{N}}=2.16$ and $r_{\mathrm{S}}=0.26$ indicate the better copolymerization ability of $\mathbf{1 c}$ than $\mathbf{1 b}$. 

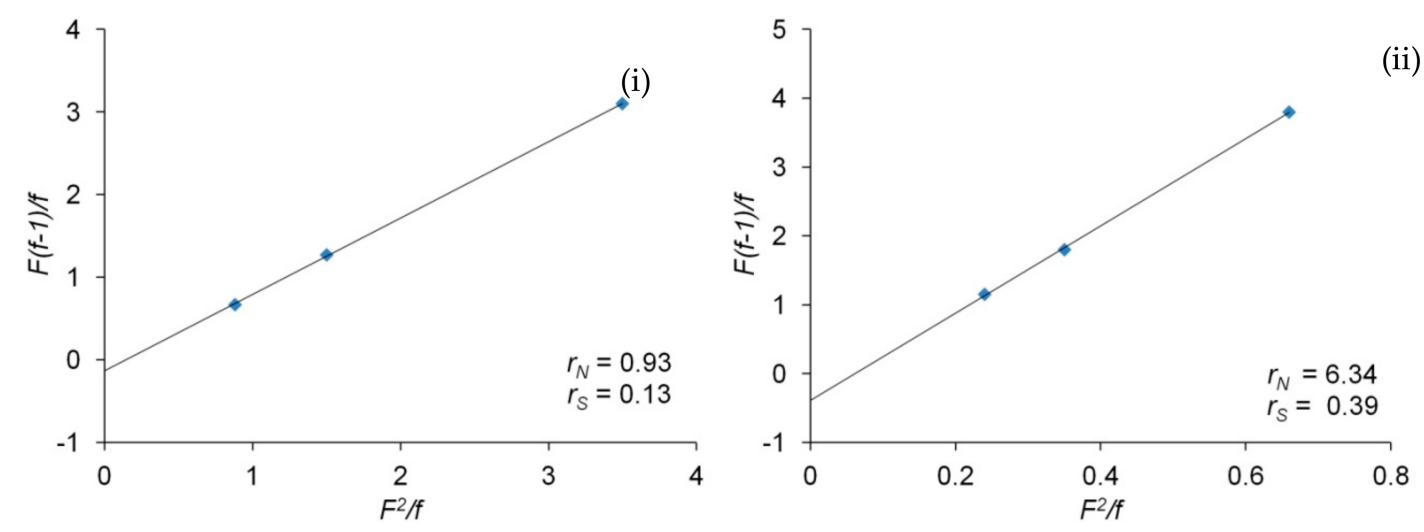

Figure 4. Fineman-Ross plots for copolymerization of $\mathrm{N} / \mathrm{S}$ by $\mathbf{1 b}$ with (i) MMAO and (ii) $\mathrm{B}\left(\mathrm{C}_{6} \mathrm{~F}_{5}\right)_{3}$.

The $T_{g}$ values determined by DSC are shown in Table 3 and are plotted against $\mathrm{S}$ content in Figure 3ii. The plot is in good accordance with that of the MMAO system, but extends to the higher $\mathrm{S}$ content as indicated by the monomer reactivity ratios. The lowest $T_{g}$ value of $128^{\circ} \mathrm{C}$ (Supplementary Figure S12) was obtained by the copolymer with S content of $59 \mathrm{~mol} \%$ and $M_{n}$ of 78,000 (Table 3, Run 31). The 1-B $\left(\mathrm{C}_{6} \mathrm{~F}_{5}\right)_{3}$ system gave the copolymers with high molecular weights and high $\mathrm{S}$ contents, compared with the 1-MMAO system, although the activity was low.

The lower activity would be due to the deactivation by impurities in the absence of scavenging reagents. Therefore, we conducted N/S copolymerization with $1 \mathrm{a}-\mathrm{B}\left(\mathrm{C}_{6} \mathrm{~F}_{5}\right)_{3}$ in the presence of the reaction mixture of ${ }^{t} \mathrm{Bu}_{3} \mathrm{Al}$ and $2,6-{ }^{t} \mathrm{Bu}_{2}-p$-cresol. The addition of the scavenger increased the activity, keeping the same $\mathrm{S}$ content and the $M_{n}$ value reached 103,000 (Table 3, Run 35). The results indicate the potentiality of $\mathbf{1}-\mathrm{B}\left(\mathrm{C}_{6} \mathrm{~F}_{5}\right)_{3}$ for $\mathrm{N} / \mathrm{S}$ copolymerization.

\subsection{Optical Property of the N/S Copolymer}

The light transmittance of the N/S copolymer thin film with the thickness about $100 \mu \mathrm{m}$ is displayed in Supplementary Figure S13 (Table 3, Run 35). The copolymer showed the transmittance above 85\% in the visible light region $(300-800 \mathrm{~nm})$.

\section{Conclusions}

Copolymerizations of $\mathrm{N}$ and $\mathrm{S}$ were achieved by anilinonaphthoquinone-ligated nickel-complexes using MMAO or $\mathrm{B}_{(}\left(\mathrm{C}_{6} \mathrm{~F}_{5}\right)_{3}$ as cocatalyst. The 1-MMAO system showed higher activity than the 1-B $\left(\mathrm{C}_{6} \mathrm{~F}_{5}\right)_{3}$ system, whereas the latter system produced the copolymers with higher molecular weight and higher styrene incorporation. The molecular weights of N/S copolymers obtained by $1-\mathrm{B}\left(\mathrm{C}_{6} \mathrm{~F}_{5}\right)_{3}$ were the highest among those of the copolymers reported previously using nickel-, copper-, and titanium-based catalytic systems.

Supplementary Materials: The following are available online at http:/www.mdpi.com/2073-4360/11/7/1100/s1, Synthesis of ligand 1c; Figure S1 ${ }^{1} \mathrm{H}$ NMR spectrum of ligand 1c; Figure S2 ${ }^{13} \mathrm{C}$ NMR spectrum of ligand 1c; Synthesis of complex 1c; Figure S3 ${ }^{1} \mathrm{H}$ NMR spectrum of complex 1c; Figure S4 ${ }^{31} \mathrm{P}$ NMR spectrum of complex 1c; Figure S5 ${ }^{1} \mathrm{H}$ NMR spectra of N/S copolymers obtained by Run 15, Run 9, and Run 3; Figure S6 GPC traces of N/S copolymers obtained by Run 7, Run 8, and Run 9; Figure S ${ }^{1} \mathrm{H}$ NMR spectra of N/S copolymers obtained by Run 25, Run 22, and Run 19; Figure S8 DSC curves of N/S copolymers obtained by Run 6 and Run 17; Figure S9 ${ }^{1} \mathrm{H}$ NMR spectra of N/S copolymers obtained by Run 31 and Run 34; Figure S10 GPC traces of N/S copolymers obtained by Run 30 and Run 33; Figure S11 Fineman-Ross plot for N/S copolymerization by 1c-MMAO; Table S1 Effects of monomer ratio of N/S copolymerization by $1 \mathrm{~b}-\mathrm{B}\left(\mathrm{C}_{6} \mathrm{~F}_{5}\right)_{3}$; Figure S12 DSC curve of N/S copolymer obtained by Run 31; Figure S13 the light transmittance of N/S copolymer thin film obtained by run 35 .

Author Contributions: Conceptualization, T.S.; methodology, S.I.C. and R.T.; polymer synthesis, S.I.C; analysis, S.I.C., R.T. and Y.N.; writing-original draft preparation, S.I.C.; editing, T.S.; review, R.T. and Y.N.; funding acquisition, T.S. 
Funding: Partial financial support from a Grant-in-Aid for Scientific Research from the Japan Society for the Promotion of Science (No. 18H02036).

Acknowledgments: This work was supported in part by a Grant-in-Aid for Scientific Research from the Japan Society for the Promotion of Science (No. 18H02036). Cocatalysts were kindly donated by Tosoh Finechem Co.

Conflicts of Interest: The authors declare no conflict of interest.

\section{References}

1. Chen, M.; Zou, W.P.; Cai, Z.G.; Chen, C.L. Norbornene homopolymerization and copolymerization with ethylene by phosphine- sulfonate nickel catalysts. Polym. Chem. 2015, 6, 2669-2676. [CrossRef]

2. Pei, L.X.; Tang, Y.; Gao, H.Y. Homo- and Copolymerization of Ethylene and Norbornene with Anilido-Imine Chromium Catalysts. Polymers 2016, 8, 69. [CrossRef] [PubMed]

3. Meng, J.F.; Li, X.; Ni, X.F.; Shen, Z.Q. High transparent alternate copolymer of norbornene with isoprene catalyzed by bis(phenoxy-imine) titanium complex. RSC Adv. 2016, 6, 19351-19356. [CrossRef]

4. Gilliom, L.R.; Grubbs, R.H. Titanacyclobutanes derived from strained, cyclic olefins: The living polymerization of norbornene. J. Am. Chem. Soc. 1986, 108, 733-742. [CrossRef]

5. Nguyen, S.T.; Johnson, L.K.; Grubbs, R.H.; Ziller, J.W. Ring-opening metathesis polymerization (ROMP) of norbornene by a Group VIII carbene complex in protic media. J. Am. Chem. Soc. 1992, 114, 3974-3975. [CrossRef]

6. Kennedy, J.P.; Makowski, H.S. Carbonium Ion Polymerization of Norbornene and Its Derivatives. J. Macromol. Sci. Chem. 1967, A1, 345-370. [CrossRef]

7. Gaylord, N.G.; Mandal, B.M.; Martan, M. Peroxide-induced polymerization of norbornene. J. Polym. Sci. Polym. Lett. Ed. 1976, 14, 555-559. [CrossRef]

8. Gaylord, N.G.; Deshpande, A.B. Structure of "vinyl-type" polynorbornenes prepared with ziegler-natta catalysts. J. Polym. Sci. Polym. Lett. Ed. 1976, 14, 613-617. [CrossRef]

9. Gaylord, N.G.; Deshpande, A.B.; Mandal, B.M.; Martan, M. Poly-2,3- and 2,7-Bicyclo[2.2.1]hept-2-enes: Preparation and Structures of Polynorbornenes. J. Macromol. Sci. Chem. 1977, A11, 1053-1070. [CrossRef]

10. Rush, S.; Reinmuth, A.; Risse, W. Palladium(II)-Catalyzed Olefin Addition Polymerizations of 3,3-Dialkyl-Substituted Cyclopropenes. Macromolecules 1997, 30, 7375-7385. [CrossRef]

11. Goodall, L.; McIntosh III, L.H.; Rhodes, L.F. New catalysts for the polymerization of cyclic olefins. Macromol. Symp. 1995, 89, 421-432. [CrossRef]

12. Seehof, N.; Mehler, C.; Breunig, S.; Risse, W. $\mathrm{Pd}^{2+}$ catalyzed addition polymerizations of norbornene and norbornene derivatives. J. Mol. Catal. 1992, 76, 219-228. [CrossRef]

13. Grove, N.R.; Kohl, P.A.; Allen, S.A.B.; Jayaraman, S.; Shick, R. Functionalized Polynorbornene Dielectric Polymers: Adhesion and Mechanical Properties. J. Polym. Sci. Part. B Polym. Phys. 1999, 37, 3003-3010. [CrossRef]

14. Janiak, C.P.; Lassahn, G. The Vinyl Homopolymerization of Norbornene. Macromol. Rapid Commun. 2001, 22, 479-492. [CrossRef]

15. Boggioni, L.; Tritto, I. State of the art of cyclic olefin polymers. MRS Bull. 2013, 38, 245-251. [CrossRef]

16. He, X.; Deng, Y.; Jiang, X.; Wang, Z.; Yang, Y.; Han, Z.; Chen, D. Copolymerization of norbornene and butyl methacrylate at elevated temperatures by a single centre nickel catalyst bearing bulky bis( $\alpha$-diimine) ligand with strong electron-withdrawing groups. Polym. Chem. 2017, 8, 2390-2396. [CrossRef]

17. Shiono, T.; Sugimoto, M.; Hasan, T.; Cai, Z.; Ikeda, T. Random Copolymerization of Norbornene with Higher 1-Alkene with ansa-Fluorenylamidodimethyltitanium Catalyst. Macromolecules 2008, 41, 8292-8294. [CrossRef]

18. Cai, Z.; Harada, R.; Nakayama, Y.; Shiono, T. Highly Active Living Random Copolymerization of Norbornene and 1-Alkene with ansa-Fluorenylamidodimethyltitanium Derivative: Substituent Effects on Fluorenyl Ligand. Macromolecules 2010, 43, 4527-4531. [CrossRef]

19. Xing, Y.; Chen, Y.; He, X.; Nie, H. Nickel(II) complexes bearing the bis( $\beta$-ketoamino) ligand for the copolymerization of norbornene with a higher 1-alkene. J. Appl. Polym. Sci. 2012, 124, 1323-1332. [CrossRef]

20. Liu, Y.M.; Ouyang, M.; He, X.H.; Chen, Y.W.; Wang, K.T. Novel Ni and $\mathrm{Pd}$ (benzocyclohexan-ketonaphthylimino) $)_{2}$ complexes for copolymerization of norbornene with octane. J. Appl. Polym. Sci. 2013, 128, 216-223. [CrossRef] 
21. Zhao, W.; Nomura, K. Copolymerizations of Norbornene and Tetracyclododecene with $\alpha$-Olefins by Half-Titanocene Catalysts: Efficient Synthesis of Highly Transparent, Thermal Resistance Polymers. Macromolecules 2016, 49, 59-70. [CrossRef]

22. Zhao, W.; Nomura, K. Design of Efficient Molecular Catalysts for Synthesis of Cyclic Olefin Copolymers (COC) by Copolymerization of Ethylene and $\alpha$-Olefins with Norbornene or Tetracyclododecene. Catalysts 2016, 6, 175. [CrossRef]

23. He, X.; Deng, Y.; Han, Z.; Yang, Y.; Chen, D. Highly symmetric single nickel catalysts bearing bulky bis( $\alpha$-diimine) ligand: Synthesis, characterization, and electron-effects on copolymerization of norbornene with 1-alkene at elevated temperarure. J. Polym. Sci: Part. A Polym. Chem. 2016, 54, 3495-3505. [CrossRef]

24. Hasan, T.; Ikeda, T.; Shiono, T. Ethene-Norbornene Copolymer with High Norbornene Content Produced by ansa-Fluorenylamidodimethyltitanium Complex Using a Suitable Activator. Macromolecules 2004, 37, 8503-8509. [CrossRef]

25. Ban, H.; Hagihara, H.; Tsunogae, Y.; Cai, Z.; Shiono, T. Highly thermostable and low birefringent norbornene-styrene copolymers with advanced optical properties: A potential plastic substrate for flexible displays. J. Polym. Sci. Part. A Polym. Chem. 2011, 49, 65-71. [CrossRef]

26. Peruch, F.; Cramail, H.; Deffieux, A. Homopolymerization and copolymerization of styrene and norbornene with Ni-based/MAO catalysts. Macromol. Chem. Phys. 1998, 199, 2221-2227. [CrossRef]

27. Zhao, C.T.; Ribeiro, M.D.R.; Portela, M.F.; Pereira Nunes, S.T. Homo- and copolymerisation of norbornene and styrene with nickel bis(acetyl acetonate)/methylaluminoxane system. Eur. Polym. J. 2001, 37, 45-54. [CrossRef]

28. Mi, X.; Ma, Z.; Wang, L.; Ke, Y.; Hu, Y. Homo- and Copolymerization of Norbornene and Styrene with Pdand Ni-Based Novel Bridged Dinuclear Diimine Complexes and MAO. Macromol. Chem. Phys. 2003, 204, 868-876. [CrossRef]

29. Suzuki, H.; Matsumura, S.; Satoh, Y.; Sogoh, K.; Yasuda, H. Random copolymerizations of norbornene with other monomers catalyzed by novel Ni compounds involving N- or O-donated ligands. React. Funct. Polym. 2004, 58, 77-91. [CrossRef]

30. Gao, H.; Chen, Y.; Zhu, F.; Wu, Q. Copolymerization of norbornene and styrene catalyzed by a novel anilido-imino nickel complex/methylaluminoxane system. J. Polym. Sci. Part. A Polym. Chem. 2006, 44, 5237-5246. [CrossRef]

31. Bao, F.; Ma, R.; Jiao, Y. Homo- and copolymerization of norbornene with styrene catalyzed by a series of copper(II) complexes in the presence of methylaluminoxane. Appl. Organomet. Chem. 2006, 20, 368-374. [CrossRef]

32. Bao, F.; Lu, X.; Chen, Y. Copolymerization of Norbornene and Styrene Catalyzed by a Series of Bis( $\beta$-ketoamine) Nickel(II) Complexes in the Presence of Methylaluminoxane. Polym. Bull. 2007, 58, 495-502. [CrossRef]

33. Ogata, K.; Nishimura, N.; Yunokuchi, T.; Toyota, A. Copolymerization of tetracyclododecene or norbornene with styrene in the presence of $\mathrm{Ni}(\mathrm{II})$ complex/MAO catalytic system: First example for transition metal catalyzed copolymerization of tetracyclododecene with styrene. J. Appl. Polym. Sci. 2008, 108, 1562-1565. [CrossRef]

34. Li, Y.; Wu, Q.; Shan, M.; Gao, M. Copolymerization of styrene and norbornene with $\beta$-diketiminato nickel/methylaluminoxane catalytic system. Appl. Organomet. Chem. 2012, 26, 225-229. [CrossRef]

35. Feng, Q.; Chen, D.; Feng, D.; Jiao, L.; Peng, Z.; Pei, L. Synthesis of poly(norbornene-co-styrene) copolymers containing high styrene incorporation using bis( $\beta$-ketoamino) copper catalysts. J. Polym. Res. 2014, 21, 497. [CrossRef]

36. Ban, H.T.; Nishii, K.; Tsunogae, Y.; Shiono, T. Synthesis and characterization of norbornene-ethylene-styrene terpolymers with a substituted ansa-fluorenylamidodimethyltitanium-based catalyst. J. Polym. Sci. Part A Polym. Chem. 2007, 45, 2765-2773. [CrossRef]

37. Okada, M.; Nakayama, Y.; Shiono, T. Highly soluble polynorbornene prepared by an anilinonaphthoquinone-ligated nickel complex via coordination-insertion polymerization. J. Organomet. Chem. 2015, 384-387. [CrossRef]

38. Okada, M.; Nakayama, Y.; Ikeda, T.; Shiono, T. Synthesis of Uniquely Branched Polyethylene by Anilinonaphthoquinone Ligated Nickel Complex Activated with Tris(pentafluorophenyl)borane. Macromol. Rapid Commun. 2006, 27, 1418-1423. [CrossRef] 
39. Okada, M.; Nakayama, Y.; Shiono, T. Synthesis of anilinonaphthoquinone-based nickel complexes and their application for olefin polymerization. J. Organomet. Chem. 2007, 692, 5183-5189. [CrossRef]

40. Ivin, K.J.; Mol, J.C. Olefin Metathesis and Metathesis Polymerization; Academic Press: San Diego, CA, USA, 1997; p. 407.

41. Benedikt, G.M.; Elce, E.; Goodall, B.L.; Kalamarides, H.A.; McIntosh, L.H.; Rhodes, L.F.; Selvy, K.T.; Andes, C.; Oyler, K.; Sen, A. Copolymerization of Ethene with Norbornene Derivatives Using Neutral Nickel Catalysts. Macromolecules 2002, 35, 8978-8988. [CrossRef]

(C) 2019 by the authors. Licensee MDPI, Basel, Switzerland. This article is an open access article distributed under the terms and conditions of the Creative Commons Attribution (CC BY) license (http://creativecommons.org/licenses/by/4.0/). 